\title{
Ultrasonography of the canine pancreas
}

\author{
La ecografía del páncreas canino
}

\author{
Michelle L Avante ${ }^{1}$ M.Sc, Priscila DA da Silva² MV, Marcus AR Feliciano ${ }^{2,3^{*}}$ Ph.D, \\ Marjury C Maronezi ${ }^{1}$ M.Sc, Ana R Simões ${ }^{2}$ M.Sc, Ricardo AR Uscategui ${ }^{2}$ D.Sc, Julio C Canola ${ }^{1}$ D.Sc.
}

\begin{abstract}
1 Univ Estadual Paulista, Jaboticabal UNESP, Department of Veterinary Surgery, School of Agrarian Sciences and Veterinary Medicine, São Paulo, Brazil. 2Univ Estadual Paulista UNESP, Department of Animal Reproduction, School of Agricultural Sciences and Veterinary Medicine, São Paulo, Brazil. ${ }^{3}$ Federal University of Recôncavo of the Bahia, Cruz das Almas, Bahia, Brazil. *Correspondence: marcusfeliciano@yahoo.com.br
\end{abstract}

Received: May 2017; Accepted: October 2017.

\begin{abstract}
This study describes the ultrasonographic techniques currently used in the evaluation of the canine pancreas. Ultrasonography was the first method to enable direct visualization of the pancreas in humans and it has been subsequently applied to animals. Currently, it is the method of choice for pancreatic evaluation and is essential as a diagnostic tool in the detection of abnormalities, especially tumors. Innovative equipment technology has led to the emergence of techniques complementary to B-mode ultrasound; such as Doppler, elastography, and contrast-enhanced ultrasonography, which have enabled more accurate diagnosis. Doppler provides information on vascular architecture and the hemodynamic aspect of blood vessels in multiple organs. ARFI elastography provides detailed images of the alterations detected by conventional examination (qualitative method) and assists in differentiating between benign and malignant processes (quantitative method). Microbubble contrast agents determine parameters related to homogeneous and heterogeneous filling of organs with microbubbles, mainly nodular areas, thus defining high and low intensity patterns.
\end{abstract}

Keywords: B-mode, Doppler, elastography, microbubbles (Source: CAB).

\section{RESUMEN}

Este estudio describe las técnicas ecográficas frecuentemente utilizadas para evaluar el pancreas del perro. La ecografía fue el primer método que permitió la visualización directa del páncreas en seres humanos y que luego se aplicó en animales. Es actualmente el método de elección para la evaluación del páncreas y es esencial como herramienta diagnóstica en la detección de anomalías, especialmente tumores. La tecnología innovadora de los equipos, llevó a la aparición de técnicas complementarias al modo B, tales como Doppler, elastografía, ecografía de contraste, que han permitido realizar diagnósticos más precisos. El Doppler proporciona información sobre la arquitectura vascular y aspectos hemodinámicos de los vasos sanguíneos en múltiples órganos. La elastografía ARFI ofrece imágenes detalladas de las alteraciones detectadas en exámenes convencionales (método cualitativo) y ayuda a diferenciar entre procesos benignos y malignos (método cuantitativo). Los agentes de contraste con microburbujas permiten determinar parámetros relacionados con el llenado homogéneo o heterogéneo de los órganos, principalmente áreas nodulares, definiendo, por tanto, patrones de alta o baja intensidad.

Palabras clave: modo B, Doppler, elastografía, microburbujas (Fuente: $C A B$ ). 


\section{INTRODUCTION}

Pancreatic disorders are common in small animals; however, they can be difficult to diagnose due to the anatomic inaccessibility of the pancreas, nonspecific clinical signs, and inconsistent laboratory findings. Therefore, ultrasonography evaluation has been increasingly used and is currently the method of choice in pancreatic assessment (1).

Ultrasonography is an important tool in the evaluation of pancreatic disorders in small animals. It was the first procedure to enable direct visualization of the pancreas in humans and it was then applied to animals. Recently, other modalities such as computed tomography, magnetic resonance imaging, and scintigraphy have been used to evaluate pancreatic disorders in humans (2). Nevertheless, ultrasonography remains the cheapest and most accessible, and technological advances have provided ultrasound devices with better image quality for pancreatic evaluation in small animals (3).

Pancreatic evaluation is completely operatordependent; therefore, good knowledge of the anatomy of the pancreas is essential (3), even though new techniques such as Doppler, elastography, and microbubble contrast agents are being used to improve the accuracy of organ evaluation.

Acoustic radiation force impulse (ARFI) is a safe non-invasive technique that measures tissue stiffness through quantitative and qualitative methods (4-5). ARFI elastography was first used in Veterinary Medicine in the differentiation of prostate and breast tumors (6) and it is currently being tested in other organs.

Doppler provides real-time information on the vascular architecture and the hemodynamic aspects of vessels in various organs (7) while contrast-enhanced ultrasonography (CEU) evaluates the perfusion of modified tissues and the vascular pattern of lesions (8). In Medicine, this technique has been used to identify pancreatic tumors based on its vascular pattern (9) and has been very effective in detecting necrotizing and acute pancreatitis (10-11-12); however, few reports are available in Veterinary Medicine.

The aim of this study was to describe and report the usefulness of the ultrasonographic techniques available for the evaluation of the canine pancreas.

\section{INTRODUCCIÓN}

Los trastornos pancreáticos son comunes en animales pequeños; sin embargo, pueden ser difíciles de diagnosticar debido a la inaccesibilidad anatómica del páncreas, signos clínicos inespecíficos y hallazgos de laboratorio inconsistentes. Por lo tanto, la evaluación por ultrasonido se ha utilizado cada vez más y actualmente es el método preferido en la evaluación pancreática (1).

La ecografía es una herramienta importante en la evaluación de trastornos pancreáticos en animales pequeños. Fue el primer procedimiento que permitió la visualización directa del páncreas en humanos y luego se aplicó a animales. Recientemente, se han utilizado otras modalidades como la tomografía computarizada, la resonancia magnética y la scintigrafía para evaluar los trastornos pancreáticos en humanos (2). Sin embargo, la ecografía sigue siendo la más económica y accesible, y los avances tecnológicos han proporcionado dispositivos de ultrasonido con mejor calidad de imagen para la evaluación pancreática en animales pequeños (3).

La evaluación pancreática depende completamente del operador; por lo tanto, es esencial un buen conocimiento de la anatomía del páncreas (3), aunque se están utilizando nuevas técnicas como el Doppler, la elastografía y los agentes de contraste de microburbujas para mejorar la precisión de la evaluación de órganos.

El impulso de fuerza de radiación acústica (IFRA) es una técnica segura no invasiva que mide la rigidez tisular mediante métodos cuantitativos y cualitativos (4-5). La elastografía IFRA se utilizó por primera vez en Medicina Veterinaria en la diferenciación de tumores de próstata y de mama (6) y actualmente se está probando en otros órganos.

El Doppler proporciona información en tiempo real sobre la arquitectura vascular y los aspectos hemodinámicos de los vasos en varios órganos (7), mientras que la ecografía mejorada por contraste (CEU) evalúa la perfusión de los tejidos modificados y el patrón vascular de las lesiones (8). En Medicina, esta técnica ha sido utilizada para identificar tumores pancreáticos con base en su patrón vascular (9) y ha sido muy efectiva en la detección de pancreatitis necrosante y aguda (10-11-12); sin embargo, hay pocos reportes disponibles en Medicina Veterinaria.

El objetivo de este estudio fue describir y reportar la utilidad de las técnicas ultrasonográficas disponibles para la evaluación del páncreas canino. 


\section{B-mode Ultrasonography}

Patients subjected to B-mode ultrasonography should fast for at least 8 hours prior to the procedure so there are no interferences from gastric contents. Trichotomy should be broad, extending to the 8th and 9th intercostal spaces for intercostal organ visualization. In most cases, the patient should be in supine position; however, right and left lateral recumbency can help scanning (3). Evaluation can be performed using linear or convex transducers, at a frequency of 7.5 to $15 \mathrm{MHz}$ in small and 5 to $8 \mathrm{MHz}$ in large dogs.

Pancreas ultrasonographic evaluation has some limiting factors, such as the patient's body condition, which may hinder the identification of the organ due to increased mesenteric fat; localized pain in patients with pancreatic disorders; gastrointestinal contents, which can impair organ visualization; and other factors particular to the pancreas such as its small size, poorly defined borders, and echogenicity similar to the adjacent mesenteric fat (3), giving it poor resolution (13).

The pancreas is a thin and elongated organ located along the greater curvature of the stomach and descending portion of the duodenum. It can be divided into three parts: right lobe, body, and left lobe. It is a homogeneous organ, isoechoic to the mesenteric fat and the caudal lobe, and slightly hyperechoic to the liver (Figure 1 ). The right lobe is long and narrow, 1 to $3 \mathrm{~cm}$ wide and $1 \mathrm{~cm}$ thick. The left lobe is shorter and wider (13-2). The diameter of the pancreatic duct is 0.4 to $0.8 \mathrm{~mm}$ in the left lobe and 0.5 to $0.9 \mathrm{~mm}$ in the right lobe (14).

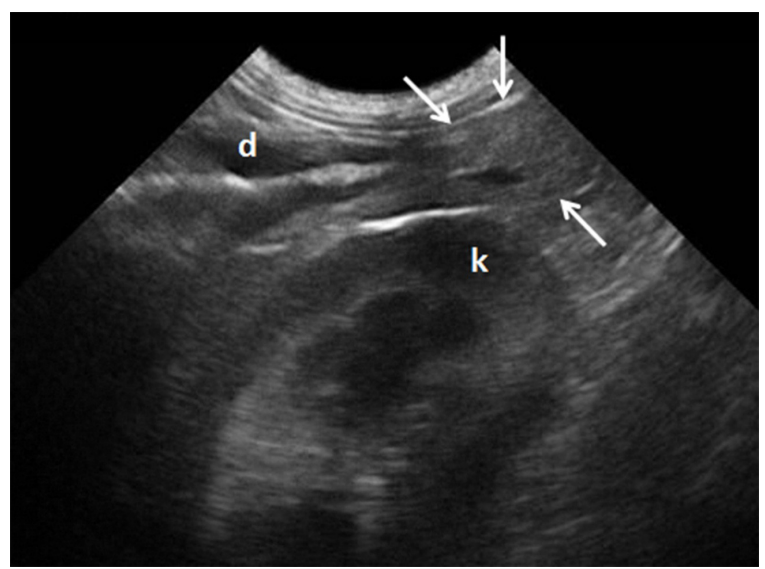

Figure 1. Ultrasonographic view of the right pancreatic lobe in a clinically healthy dog (arrows indicate organ). Pancreaticoduodenal vein viewed as an anechoic structure in the pancreas. (d) duodenum. (k) right kidney.

\section{Ecografía en modo B}

Los pacientes sometidos a una ecografía en modo B deben ayunar durante al menos 8 horas antes del procedimiento para que no haya interferencias del contenido gástrico. La tricotomía debe ser amplia, extendiéndose a los espacios intercostales $8^{\circ}$ y $9^{\circ}$ para la visualización del órgano intercostal. En la mayoría de los casos, el paciente debe estar en posición supina; sin embargo, la recostada lateral derecha e izquierda puede ayudar a escanear (3). La evaluación puede realizarse utilizando transductores lineales o convexos, a una frecuencia de 7,5 a $15 \mathrm{MHz}$ en perros pequeños y de 5 a $8 \mathrm{MHz}$ en perros grandes.

La evaluación ecográfica del páncreas tiene algunos factores limitantes, como la condición corporal del paciente, que puede dificultar la identificación del órgano debido al aumento de grasa mesentérica; dolor localizado en pacientes con trastornos pancreáticos; contenido gastrointestinal, que puede perjudicar la visualización de los órganos; y otros factores particulares del páncreas como su pequeño tamaño, bordes mal definidos y una ecogenicidad similar a la grasa mesentérica adyacente (3), lo que le da una resolución deficiente (13).

El páncreas es un órgano delgado y alargado ubicado a lo largo de la curvatura mayor del estómago y la porción descendente del duodeno. Se puede dividir en tres partes: lóbulo derecho, cuerpo y lóbulo izquierdo. Es un órgano homogéneo, isoecóico a la grasa mesentérica y al lóbulo caudal, y ligeramente hiperecóico al hígado (Figura 1). El lóbulo derecho es largo y estrecho, de $1 \mathrm{a} 3 \mathrm{~cm}$ de ancho y $1 \mathrm{~cm}$ de espesor. El lóbulo izquierdo es más corto y ancho (13-2). El diámetro del conducto pancreático es de 0,4 a $0,8 \mathrm{~mm}$ en el lóbulo izquierdo y de 0,5 a 0,9 $\mathrm{mm}$ en el lóbulo derecho (14).

La vena pancreático duodenal puede verse en el lóbulo derecho y puede rastrearse hasta las venas gastroduodenal y portal (13). Sólo las venas que drenan el lóbulo derecho son visibles mediante evaluación ecográfica (1). El lóbulo pancreático derecho se localiza entre el riñón derecho y el duodeno descendente. Una vez que el riñón ha sido identificado (transductor posicionado medialmente), el duodeno puede ser visualizado adyacente a la pared abdominal. Alternativamente, el páncreas puede ser detectado por la vena pancreático duodenal, que se encuentra paralela al duodeno descendente (3-13). 
The pancreaticoduodenal vein can be seen in the right lobe and may be traced to the gastroduodenal and portal veins (13). Only the veins that drain the right lobe are visible by ultrasonographic evaluation (1). The right pancreatic lobe is located between the right kidney and the descending duodenum. Once the kidney has been identified (transducer positioned medially), the duodenum can be visualized adjacent to the abdominal wall. Alternatively, the pancreas can be detected by the pancreaticoduodenal vein, which can be found parallel to the descending duodenum (3-13).

The body of the pancreas extends caudally to the pyloric region, and the portal vein is located left and dorsally to it. The left lobe can be found between the stomach, spleen, and left kidney (13). It originates in the body and extends dorsocaudally to gastric antrum, continuing between the stomach and transverse colon. While in dogs the left lobe is hard to be visualized due to the gastrointestinal content, in cats it is more easily seen than the right lobe. In a study with 100 dogs, reported that the left lobe was only visualized in $57 \%$ of animals, as opposed to $87 \%$ for the right lobe. The large number of animals used in the study highlights the difficulties in visualizing the left pancreatic lobe in dogs (15).

The main disorders detected by ultrasound examination of the pancreas are pancreatitis, nodular hyperplasia, cysts, neoplasms, edema, and abscesses (3-13).

Pancreatitis is the most frequent disorder that affects the exocrine pancreas in dogs and requires safe and accurate techniques to obtain a quick prognosis and avoid complications to the patient. The complications most commonly observed are pancreatic cell death and regional blood supply loss, which can trigger systemic inflammatory response and lead to death (8). The ultrasonographic findings of pancreatitis vary with the severity, extent, and duration of inflammation in the tissue itself and in adjacent tissues. In acute pancreatitis, the organ is often enlarged, with reduced echogenicity, poor definition, and increased echogenicity of the adjacent mesentery (Figure 2). In some cases, free abdominal fluid may be present and the duodenum may be thickened and irregular. In dogs, the right pancreatic lobe is usually the most affected (13).

Acute pancreatitis does not always produce sufficient alterations to be visualized on ultrasound, especially in cats. Multifocal hypoechoic areas, cystic lesions, hyperechoic regions, and mixed echogenicity patterns can also be seen in pancreatitis; as well as edema,
El cuerpo del páncreas se extiende caudalmente hasta la región pilórica, y la vena porta se localiza a la izquierda y dorsalmente hacia ella. El lóbulo izquierdo se encuentra entre el estómago, el bazo y el riñón izquierdo (13). Se origina en el cuerpo y se extiende dorso-caudalmente hasta el antro gástrico, continuando entre el estómago y el colon transverso. Mientras que en los perros el lóbulo izquierdo es difícil de visualizar debido al contenido gastrointestinal, en los gatos es más fácil de ver que el lóbulo derecho. En un estudio con 100 perros, se reportó que el lóbulo izquierdo sólo se visualizó en el $57 \%$ de los animales, en comparación con el 87\% para el lóbulo derecho. El gran número de animales utilizados en el estudio pone de manifiesto las dificultades para visualizar el lóbulo pancreático izquierdo en perros (15).

Los principales trastornos detectados por ecografía del páncreas son pancreatitis, hiperplasia nodular, quistes, neoplasias, edema y abscesos (3-13).

La pancreatitis es el trastorno más frecuente que afecta al páncreas exocrino en los perros y requiere técnicas seguras y precisas para obtener un pronóstico rápido y evitar complicaciones al paciente. Las complicaciones que se observan con mayor frecuencia son la muerte de las células pancreáticas y la pérdida de suministro sanguíneo regional, que pueden desencadenar una respuesta inflamatoria sistémica y provocar la muerte (8). Los hallazgos ecográficos de la pancreatitis varían con la gravedad, extensión y duración de la inflamación en el tejido mismo y en los tejidos adyacentes. En la pancreatitis aguda, el órgano a menudo se agranda, con una ecogenicidad reducida, una definición deficiente y una ecogenicidad incrementada del mesenterio adyacente (Figura 2). En algunos casos, puede haber líquido abdominal libre y el duodeno puede estar engrosado e irregular. En los perros, el lóbulo pancreático derecho suele ser el más afectado (13).

La pancreatitis aguda no siempre produce suficientes alteraciones para ser visualizadas en el ultrasonido, especialmente en gatos. Las áreas multifocales hipoecoicas, las lesiones quísticas, las regiones hiperecóicas y los patrones mixtos de ecogenicidad también se pueden observar en la pancreatitis, así como edema, hemorragia y necrosis. En la fase subaguda, se puede desarrollar necrosis quística, resultando en pseudoquistes. Se ha informado de edema intramural y dilatación u obstrucción de las vías biliares en casos de pancreatitis aguda (2). La pancreatitis crónica resulta de episodios recurrentes de pancreatitis. El órgano se vuelve 
hemorrhage, and necrosis. In the sub-acute phase, cystic necrosis may develop, resulting in pseudocysts. Intramural edema and dilation or obstruction of the bile ducts have been reported in cases of acute pancreatitis (2). Chronic pancreatitis results from recurrent episodes of pancreatitis. The organ becomes hyperechoic and may be smaller. However, the larger the pancreas the greater the echogenicity and more irregular the contours, the more suggestive of chronic disease.

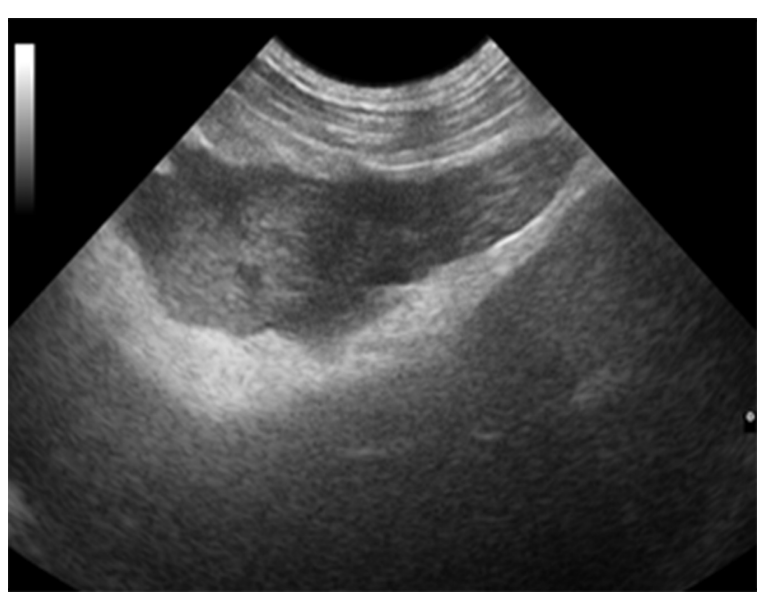

Figure 2. Acute pancreatitis in a dog. Enlarged pancreas with reduced echogenicity and increased echogenicity of the adjacent mesentery.

Nodular hyperplasia is commonly found in older dogs and is difficult to differentiate from neoplasia, the latter being typically greater than $2 \mathrm{~cm}$ and hyperplasia being smaller. In cases of pancreatic cystic lesions, differentiation of the various types of cystic pancreatitis requires histopathological analysis (2). Pancreatic masses are often poorly defined and vary in appearance according to their location (right lobe, body, or left lobe). Mass effect has been reported in cases of pancreatitis. In small animals, neoplasms are rare and difficult to differentiate from inflammatory processes. While in pancreatitis there is a diffuse reduction in pancreatic echogenicity, neoplasms are characterized by the presence of nodes or hypoechoic masses (3).

\section{Doppler}

The Doppler technology is a method that, when associated with conventional ultrasonography, provides real-time information on the vascular architecture and hemodynamic aspects of vessels. The hemodynamic parameters such as the systolic/diastolic ratio (S/D), resistance index (RI), peak systolic velocity (PSV), and pulsatility index (PI) enable comparison of flow during hiperecóico y puede ser más pequeño. Sin embargo, cuanto más grande es el páncreas, mayor es la ecogenicidad y más irregulares los contornos, más sugestivas son las enfermedades crónicas.

La hiperplasia nodular se encuentra comúnmente en perros mayores y es difícil de diferenciar de la neoplasia, siendo esta última típicamente mayor de $2 \mathrm{~cm}$ e hiperplasia más pequeña. En los casos de lesiones quísticas pancreáticas, la diferenciación de los distintos tipos de pancreatitis quística requiere un análisis histopatológico (2). Las masas pancreáticas a menudo están mal definidas y varían en apariencia de acuerdo con su localización (lóbulo derecho, cuerpo o lóbulo izquierdo). Se ha reportado un efecto de masa en casos de pancreatitis. En animales pequeños, las neoplasias son raras y difíciles de diferenciar de los procesos inflamatorios. Mientras que en la pancreatitis hay una reducción difusa de la ecogenicidad pancreática, los neoplasmas se caracterizan por la presencia de ganglios o masas hipoecóicas (3).

\section{Doppler}

La tecnología Doppler es un método que, asociado a la ecografía convencional, proporciona información en tiempo real sobre la arquitectura vascular y los aspectos hemodinámicos de los vasos. Los parámetros hemodinámicos como la relación sistólica/diastólica (S/D), el índice de resistencia (RI), la velocidad sistólica máxima (PSV) y el índice de pulsatilidad (PI) permiten la comparación del flujo durante las fases del ciclo cardíaco. Estos índices se utilizan para ayudar en la evaluación de estenosis, trombosis o análisis de vasos periféricos (7).

Estudios previos usando Doppler han reportado buenos resultados y aplicabilidad en animales. En Medicina Veterinaria, la eficacia de esta técnica ha sido demostrada en estudios hemodinámicos de tejidos y ha sido fundamental en la evaluación de la neovascularización en alteraciones tisulares (16). Además, puede utilizarse en el diagnóstico precoz del embarazo, el monitoreo gestacional y la diferenciación de tumores de mama benignos y malignos (16-18).

Por el contrario, se dispone de pocos informes sobre la aplicabilidad del Doppler en la evaluación de los índices vasculares pancreáticos en Medicina Veterinaria y se utiliza principalmente para diferenciar la vena pancreatoduodenal del conducto pancreático y para evaluar la vascularización (13). 
the phases of the cardiac cycle. These indexes are used to assist in the evaluation of stenosis, thrombosis, or in peripheral vessel analysis (7).

Previous studies using Doppler have reported good results and applicability in animals. In Veterinary Medicine, the effectiveness of this technique has been proven in hemodynamic studies of tissues and it has been fundamental in the assessment of neovascularization in tissue alterations (16). Furthermore, it can be used in early pregnancy diagnosis, gestational monitoring, and differentiation of benign and malignant breast tumors (16-18).

In contrast, few reports are available on the applicability of Doppler in the assessment of pancreatic vascular indexes in Veterinary Medicine and is mostly used to differentiate the pancreaticoduodenal vein from the pancreatic duct and to assess vascularization (13).

Colored Doppler is used to analyze the vascular characteristics of affected pancreatic parenchyma, including the presence or absence of neovascularization, vessel type (around, network, or mosaic), and their location (peri or intra-pancreatic).

In Medicine, studies have shown that Doppler ultrasound has increasingly contributed to the diagnosis and staging of pancreatic diseases, due to the significant increase in the sensitivity of this technique. Doppler is used to assess the intra and peri-pancreatic vasculature, such as the portal vein, splenic vessels, mesenteric vessels, and large vessels. Inflammatory masses are described as hypervascular; and carcinoma, the most common pancreatic neoplasm in humans, as hypovascular. Doppler has a sensitivity of $93 \%$ and specificity of $77 \%$ in cases of suspected masses and an accuracy of $88 \%$ pancreatic cancer diagnosis. In the presence of collateral circulation, these numbers increase to $97 \%$ sensitivity and $92 \%$ specificity, with an accuracy of $95 \%(19,20)$.

Contrast-enhanced Doppler ultrasonography appears to be useful in pancreatic assessment; however, further studies are needed. A study in cats has shown a significant increase in vascularity and blood volume in animals with pancreatic disease when compared to controls. Higher values were detected with power Doppler than with color Doppler, and were more effective at post-contrast than at pre-contrast time (21).

In Veterinary Medicine, few studies have been reported on the use of Doppler in pancreatic and peri-pancreatic assessment; however, further
El Doppler color se utiliza para analizar las características vasculares del parénquima pancreático afectado, incluyendo la presencia o ausencia de neovascularización, el tipo de vaso (alrededor, red o mosaico) y su ubicación (peri o intrapancreática).

En Medicina, los estudios han demostrado que el ultrasonido por Doppler ha contribuido cada vez más al diagnóstico y estadificación de las enfermedades pancreáticas, debido al aumento significativo de la sensibilidad de esta técnica. El Doppler se utiliza para evaluar la vasculatura intrapancreática y peripancreática, como la vena porta, los vasos esplénicos, los vasos mesentéricos y los grandes vasos. Las masas inflamatorias se describen como hipervasculares; y el carcinoma, el neoplasma pancreático más común en humanos, como hipovascular. El Doppler tiene una sensibilidad del $93 \%$ y una especificidad del $77 \%$ en casos de sospecha de masas y una precisión del $88 \%$ en el diagnóstico del cáncer de páncreas. En presencia de circulación de colateral, estas cifras aumentan hasta el $97 \%$ de sensibilidad y el $92 \%$ de especificidad, con una precisión del $95 \%(19,20)$.

La ecografía Doppler mejorada con contraste parece ser útil en la evaluación pancreática; sin embargo, se necesitan estudios adicionales. Un estudio en gatos ha mostrado un aumento significativo en la vascularidad y el volumen sanguíneo en animales con enfermedad pancreática en comparación con los controles. Se detectaron valores más altos con el Doppler de potencia que con el Doppler color, y fueron más efectivos en el post-contraste que en el tiempo de pre-contraste (21).

En Medicina Veterinaria, se han reportado pocos estudios sobre el uso del Doppler en la evaluación pancreática y peripancreática; sin embargo, se están realizando más investigaciones basadas en datos de la medicina humana, con el fin de contribuir a la evaluación y diagnóstico de los trastornos pancreáticos.
Elastografía de Radiación Acústica de la Fuerza de Impulso (ARFI). Esta técnica de ultrasonido consiste en la extensión tecnológica de una de las herramientas médicas más antiguas, la palpación, que tiene limitaciones en la detección de masas profundas relativas a la superficie de la piel, así como otras alteraciones existentes en el tejido enfermo, como la densidad tisular, el contenido de agua y la capacidad de interacción acústica. Estas limitaciones han llevado al desarrollo de un área de diagnóstico por imágenes que permite el diagnóstico más allá 
research is being done based on data from human medicine, in order to contribute to the evaluation and diagnosis of pancreatic disorders.

\section{Acoustic Radiation Force Impulse (ARFI)} Elastography. This ultrasound technique consists in the technological extension of one of the oldest medical tools, palpation, which has limitations in detecting deep masses relative to the skin surface, as well as other existing alterations in the diseased tissue, such as tissue density, water content, and acoustic interaction capacity. These limitations have led to the development of an area of diagnostic imaging that enables diagnosis beyond the limits of palpation (22). The results previously obtained using new ultrasound techniques have been promising, which has ensured their use in Veterinary Medicine, especially in dogs, due to their low cost and scientific similarity to humans.

Elastography was developed in the early nineties and is considered a promising method to assess the elasticity of tissues, enabling the study of tissue stiffness. Since then, various methods for assessing tissue elasticity have emerged (compression, acoustic radiation force impulse - ARFI, and real-time shear velocity - RSV), (4).

ARFI elastography provides quantitative and qualitative measurements of tissue stiffness with low interobserver variability (22). Quantitative ARFI employs a primary acoustic pulse towards the region of interest, promoting the formation of propagating pressure waves capable of deforming tissues, and the speed of propagation of these pressure waves (shear) is then measured. The propagation velocity and attenuation of waves are related to the stiffness and viscoelasticity of the tissue, with greater speed being observed in harder tissues (23)(Figure 3).

Qualitative ARFI uses short high-intensity acoustic pulses that deform the tissue elements and create a static map (elastogram) of relative tissue stiffness. This diagnostic tool provides a grey scale map of the relative stiffness of the tissues from the studied area, which is then compared to the corresponding conventional ultrasound image. Generally, lighter areas represent more deformable tissues than dark areas (24).

In Medicine, elastography has been used mainly in the identification and differentiation of breast tumors, prostate tumor diagnosis, monitoring of focal and fibrotic hepatic lesions, the study of the structural properties of the kidneys (25), myocardial evaluation (26), musculoskeletal and gastrointestinal analysis (27), thyroid nodule de los límites de la palpación (22). Los resultados obtenidos anteriormente utilizando nuevas técnicas de ultrasonido han sido prometedores, lo que ha asegurado su uso en Medicina Veterinaria, especialmente en perros, debido a su bajo costo y similitud científica con los humanos.

La Elastografía fue desarrollada a principios de los años noventa y se considera un método prometedor para evaluar la elasticidad de los tejidos, permitiendo el estudio de la rigidez de los tejidos. Desde entonces, han surgido varios métodos para evaluar la elasticidad tisular (compresión, Radiación Acústica de la Fuerza de Impulso - ARFI, y velocidad cortante en tiempo real - RSV), (4).

La elastografía ARFI proporciona mediciones cuantitativas y cualitativas de la rigidez de los tejidos con una baja variabilidad entre observadores (22). El ARFI cuantitativo emplea un pulso acústico primario hacia la región de interés, promoviendo la formación de ondas de presión propagadoras capaces de deformar los tejidos, y luego se mide la velocidad de propagación de estas ondas de presión (cizallamiento). La velocidad de propagación y la atenuación de las ondas están relacionadas con la rigidez y viscoelasticidad del tejido, observándose mayor velocidad en los tejidos más duros (23), (Figura 3).

El ARFI cualitativo utiliza pulsos acústicos cortos de alta intensidad que deforman los elementos tisulares y crean un mapa estático (elastograma) de la rigidez relativa del tejido. Esta herramienta de diagnóstico proporciona un mapa en escala de grises de la rigidez relativa de los tejidos del área estudiada, que luego se compara con la imagen de ultrasonido convencional correspondiente. Generalmente, las áreas más claras representan más tejidos deformables que las áreas oscuras (24).

En Medicina, la elastografía se ha utilizado principalmente en la identificación y diferenciación de tumores de mama, diagnóstico de tumores de próstata, monitorización de lesiones hepáticas focales y fibróticas, estudio de las propiedades estructurales de los riñones (25), evaluación del miocardio (26), análisis musculoesquelético y gastrointestinal (27), investigación de nódulos tiroideos, caracterización de la aterosclerosis y control de los resultados de la ablación renal en pacientes humanos (28). En Medicina Veterinaria, el uso de la elastografía ARFI es nuevo y experimental. Se ha utilizado en la evaluación de tumores de mama en perras (5), la estandarización de los valores de referencia en hígado y riñón, y la evaluación del bazo en perros adultos (29). 


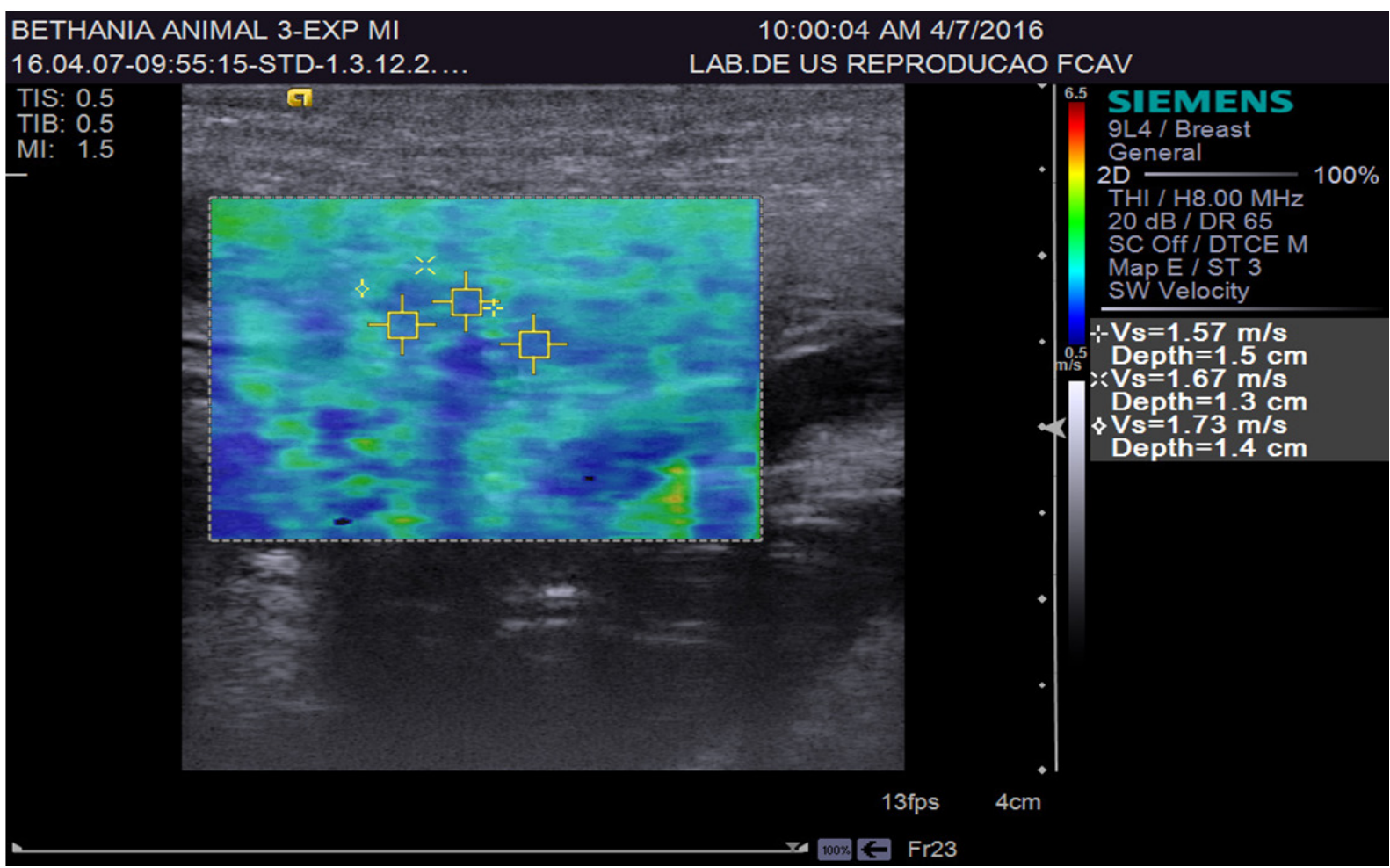

Figure 3. Quantitative ARFI ultrasonography of the right pancreatic lobe in a dog.

research, characterization of atherosclerosis, and control of renal ablation results in human patients (28). In Veterinary Medicine, the use of ARFI elastography is new and experimental. It has been used in the evaluation of breast tumors in female dogs (5), standardization of reference values in the liver and kidney, and spleen evaluation in adult dogs (29).

A study using 52 healthy human patients and 46 with chronic pancreatitis evaluated by ARFI elastography reported that the pancreas of patients with chronic disease showed higher elasticity than those of healthy patients. Quantitative values obtained from these patients were 0.78 to 1.40 $\mathrm{m} / \mathrm{s}$. The positive, negative, sensitivity, and specificity predictive values obtained were 69, 78,75 , and $72 \%$; respectively (30). In another study, the quantitative mean values reported were $1.28 \mathrm{~m} / \mathrm{s}$ in normal pancreas, $1.25 \mathrm{~m} / \mathrm{s}$ in chronic inflammatory disease, and $3.28 \mathrm{~m} / \mathrm{s}$ in acute inflammatory disease (31).

Contrast Enhanced Ultrasound (CEUS). CEU is a recent imaging technique that uses stabilized gas bubbles to enhance the ultrasound image. Due to their high reflectiveness, the microbubbles agents are capable of increasing the Doppler signal, enabling the detection of flows hardly detectable by traditional methods (32).
Un estudio que utilizó 52 pacientes humanos sanos y 46 con pancreatitis crónica evaluados por la elastografía de ARFI informó que el páncreas de los pacientes con enfermedades crónicas mostró mayor elasticidad que el de los pacientes sanos. Los valores cuantitativos obtenidos de estos pacientes fueron de 0,78 a 1,40 m/s. Los valores predictivos positivos, negativos, de sensibilidad y de especificidad obtenidos fueron $69,78,75$ y $72 \%$, respectivamente (30). En otro estudio, los valores medios cuantitativos reportados fueron de $1,28 \mathrm{~m} / \mathrm{s}$ en el páncreas normal, 1,25 m/s en la enfermedad inflamatoria crónica y 3,28 m/s en la enfermedad inflamatoria aguda (31).

\section{Ultrasonido mejorado por contraste (CEUS).}

CEUS es una técnica de imagenología reciente que utiliza burbujas de gas estabilizadas para mejorar la imagen de ultrasonido. Debido a su alta reflectividad, los agentes de microburbujas son capaces de aumentar la señal Doppler, permitiendo la detección de flujos difícilmente detectables por los métodos tradicionales (32).

Estudios innovadores en humanos y animales han demostrado que la CEUS es una técnica de imagenología que puede ser usada para ayudar a apoyar el modo B y mapear el Doppler en la evaluación hemodinámica de varios órganos, 
Innovative studies in humans and in animals have shown that $\mathrm{CEU}$ is an imaging technique that can be used to assist B-mode and Doppler mapping in the hemodynamic evaluation of various organs, including the hemodynamic behavior of the canine pancreas. This technique has been used in Medicine for the assessment of myocardial viability, breast cancer detection in women, intestinal ischemia, peripheral arterial disease, hepatic vascular diseases, and renal perfusion studies (33); among others. In Veterinary Medicine, studies using this method are recent but its use has been reported in the evaluation of liver, spleen, kidney, prostate (34), and pancreatic tissues (8). In a study conducted in cats, testicles from healthy animals have also been evaluated (35).

This technique defines parameters related to homogeneous or heterogeneous filling of organs by microbubbles, mainly nodular areas within the abnormal tissue, enabling the classification of intensity patterns: high intensity (hyperenhanced), wherein the mass cannot be differentiated from the surrounding tissue (isoenhanced); and low intensity patterns (hypoenhanced) (36). It can also be used to evaluate vascular filling times, from the time of injection of the contrast in the bloodstream to the start of organ perfusion (wash-in); contrast peak (highlight), which is the highest moment of infusion; and total time of contrast output from the parenchyma (wash-out). This pattern of microvascular filling is of great importance in early detection of small masses at the early stages of evolution and hypervascularization of aggressive tumors, aiding non-invasively in the differentiation between malignant and benign neoplasms (37).

A recent study compared the perfusion characteristics and enhancement patterns of the pancreas in healthy dogs and those with pancreatitis using CEU. It was reported that in dogs with acute pancreatitis the mean quantity of pixels and peak intensity of the parenchyma were significantly higher than in normal dogs (8). Another recent study comparing contrast tomography with CEU in cases of acute pancreatitis concluded that ultrasonographic examination may be an alternative to contrast tomography and should be the method of choice (38). However, other alterations such as adenocarcinoma, fibrosis, pseudocysts, and pancreatic necrosis are difficult to be differentiated by this technique due to their lack of vascularization (8).

Furthermore, evaluated the use of CEU with microbubble agents in the pancreas of healthy incluyendo el comportamiento hemodinámico del páncreas canino. Esta técnica ha sido utilizada en Medicina para la evaluación de la viabilidad miocárdica, detección de cáncer de mama en mujeres, isquemia intestinal, enfermedad arterial periférica, enfermedades vasculares hepáticas y estudios de perfusión renal (33), entre otros. En Medicina Veterinaria, los estudios que utilizan este método son recientes, pero se ha reportado su uso en la evaluación del hígado, bazo, riñón, próstata (34) y tejidos pancreáticos (8). En un estudio realizado en gatos, también se han evaluado testículos de animales sanos (35).

Esta técnica define parámetros relacionados con el llenado homogéneo o heterogéneo de órganos por microburbujas, principalmente áreas nodulares dentro del tejido anormal, permitiendo la clasificación de patrones de intensidad: alta intensidad (hiperenfavorecida), en la que la masa no puede ser diferenciada del tejido circundante (isoenfavorecida); y patrones de baja intensidad (hipo-enfavorecida) (36). También se puede utilizar para evaluar los tiempos de llenado vascular, desde el momento de la inyección del contraste en el torrente sanguíneo hasta el inicio de la perfusión de órganos (lavado); el pico de contraste (realce), que es el momento más alto de la infusión; y el tiempo total de salida de contraste del parénquima (lavado). Este patrón de llenado microvascular es de gran importancia en la detección precoz de pequeñas masas en estadios tempranos de evolución e hipervascularización de tumores agresivos, ayudando de forma no invasiva en la diferenciación entre neoplasias malignas y benignas (37).

Un estudio reciente comparó las características de perfusión y los patrones de realce del páncreas en perros sanos y en aquellos con pancreatitis utilizando UCE. Se informó que en perros con pancreatitis aguda la cantidad media de píxeles y la intensidad máxima del parénquima eran significativamente mayores que en perros normales (8). Otro estudio reciente que compara la tomografía de contraste con la CEUS en casos de pancreatitis aguda concluyó que el examen ecográfico puede ser una alternativa a la tomografía de contraste y debe ser el método de elección (38). Sin embargo, otras alteraciones como adenocarcinoma, fibrosis, pseudoquistes y necrosis pancreática son difíciles de diferenciar por esta técnica debido a su falta de vascularización (8).

Además, habiendo evaluado el uso de CEUS con agentes de microburbujas en el páncreas de gatos sanos, se informó que el contraste permitía una mejor definición de los bordes 
cats, it was reported that the contrast allowed better definition of the pancreatic borders. This data may be useful as a reference for future studies in pancreatic disorders in cats (12).

Although the CEU is valuable in hemodynamic investigation of tissue perfusion, in the diagnosis of neoplastic diseases, and in traumatic or necrotic lesions due to differences of blood flow, histopathological analysis will always be the gold standard for the diagnosis of lesions (8).

\section{Conclusion}

Ultrasonography is an affordable and non-invasive technique that provides important information on organ parenchyma and adjacent structures. It is an essential tool in the diagnosis of pancreatic disorders and provides quick prognosis. In addition, new techniques are being increasingly studied to complement the information obtained by conventional ultrasound and contribute to better diagnostic quality.

\section{Conflicts of interest}

The authors declare they have no conflicts of interest with regard to the work presented in this report. pancreáticos. Estos datos pueden ser útiles como referencia para estudios futuros sobre trastornos pancreáticos en gatos (12).

Aunque la CEUS es valiosa en la investigación hemodinámica de la perfusión tisular, en el diagnóstico de enfermedades neoplásicas y en lesiones traumáticas o necróticas por diferencias de flujo sanguíneo, el análisis histopatológico siempre será la regla de oro para el diagnóstico de lesiones (8).

\section{Conclusión}

La ecografía es una técnica asequible y no invasiva que proporciona información importante sobre el parénquima de los órganos y las estructuras adyacentes. Es una herramienta esencial en el diagnóstico de los trastornos pancreáticos y proporciona un pronóstico rápido. Además, cada vez se estudian nuevas técnicas para complementar la información obtenida por el ultrasonido convencional y contribuir a una mejor calidad diagnóstica.

\section{Conflicto de intereses}

Los autores declaran que no tienen conflictos de intereses con respecto al trabajo presentado en este informe.

\section{REFERENCES}

1. Saunders HM. Ultrasonography of the pancreas. Probl Vet Med 1991; 3(4):583-603.

2. Mattoon JS, Nyland TG. Pancreas. Small Animal Diagnostic Ultrasound. 3 end. St. Luis: Elsevier; 2015.

3. Feliciano MAR, Canola JC, Vicente WRR. Diagnóstico por Imagem em Cães e Gatos. São Paulo: MedVet; 2015.

4. Dudea SM, Giurgiu CR, Dumitriu D, Chiorean A, Ciurea A, Botar-Jid C, et al. Value of ultrasound elastography in the diagnosis and management of prostate carcinoma. Med Ultrason 2011; 13(1):45-53.

5. Feliciano MAR, Maronezi MC, Pavan L, Castanheira TL, Simões APR, Carvalho CF, et al. ARFI elastography as complementary diagnostic method of mammary neoplasm in female dogs - preliminary results. J Small Anim Pract 2014; 55(10):504-508.
6. Maronezi MC, Feliciano MAR, Crivellenti LZ, Simões APR, Bartlewski PM, Gill I, et al. Acoustic radiation force impulse elastography of the spleen in healthy dogs of different ages. J Small Anim Pract 2015; 56(6):393-397.

7. Carvalho CF, Chammas MC, Cerri GG. Princípios físicos do doppler em ultra-sonografia. Cienc Rural 2008; 38(3):872-879.

8. Rademacher N, Schur D, Gaschen F, Kearney M, Gaschen L. Contrast-enhanced ultrasonography of the pancreas in healthy dogs and in dogs with acute pancreatitis. Vet Radiol Ultrasound 2016; 57(1):58-64.

9. D'onofrio M, Zamboni G, Faccioli N, Capelli P, Pozzi MR. Ultrasonography of the pancreas. 4. Contrast-enhanced imaging. Abdom Imaging 2007; 32(2):171-81. 
10. Ripollé T, Martinez MJ, López E, Castello I, Delgado F. Contrast-enhanced ultrasound in the staging of acute pancreatitis. Eur Radiol $2010 ; 20(10): 2518-23$.

11. Andersen $A M$, Malmstrom ML, Novovic S, Nissen FH, Jensen LI, Holm O, Hansen MB. Contrast enhanced ultrasonography in acute pancreatitis. Pancreatol 2013; 13(1):95-97.

12. Diana A, Linta N, Cipone M, Fedone V, Steiner JM, Fracassi $F$, et al. Contrastenhanced ultrasonography of the pancreas in healthy cats. BMC Vet Res 2015; 11:64.

13. Penninck D, D'anjou M-A. Atlas de Ultrassonografia de Pequenos Animais. Rio de Janeiro: Guanabara Koogan; 2011.

14. Penninck DG, Zeyen U, Taeymans ON, Webster CR. Ultrasonographic measurement of the pancreas and pancreatic duct in clinically normal dogs. Am J Vet Res 2013; 74(3):433-437.

15. Barberet V, Schreurs E, Rademacher, N, Nitzl D, Taeymans O, Duchateau L, et al. Quantification of the effect of various patient and image factors on ultrasonographic detection of select canine abdominal organs. Vet Radiol Ultrasound 2008; 49(3):273-276.

16. Feliciano MAR, Vicente WRR, Silva MAM. Conventional and Doppler ultrasound for the differentiation of benign and malignant canine mammary tumours. J Small Anim Pract 2012; 53(6):332-337.

17. Feliciano MAR, Muzzi LAL, Leite CAL, Junqueira MA. Two-dimensional conventional, high resolution two-dimensional and threedimensional ultrasonography in the evaluation of pregnant bitch. Arq Bras Med Vet Zootec 2007; 59(5):1333-1337.

18. Miranda SA, Domingues SFS. Conceptus ecobiometry and triplex Doppler ultrasonography of uterine and umbilical arteries for assessment of fetal viability in dogs. Theriogenology 2010; 74(4):608-617.

19. Saftoiu A. Endoscopic ultrasound-guided fine needle aspiration biopsy for the molecular diagnosis of gastrointestinal stromal tumors: shifting treatment options. J Gastrointestin Liver Dis 2008; 17(2):131-133.

20. Vervloet E, Martins WP. O papel da ultrassonografia no câncer de pâncreas. Escola de Ultrassonografia e Reciclagem Médica de Ribeirão Preto 2011; 3(2):41-44.
21. Rademacher N, Ohlerth S, Scharf G, Laluhova D, Sieber-Ruckstuhl N, Alt M, et al. Contrast-Enhanced Power and Color Doppler Ultrasonography of the Pancreas in Healthy and Diseased Cats. J Vet Intern Med 2008; 22(6): 1310-1316.

22. Carvalho CF, Chammas MC, Oliveira CPMS, Cogliati B, Carrilho FJ, Cerri GG. Elastography and contrast-enhanced ultrasonography improves early detection of hepatocellular carcinoma in experimental model of NASH. J Clin Exp Hepatol 2013; 3(2):96-101.

23. Comstock C. Ultrasound elastography of breast lesions. Ultrasound Clin 2011; 6(3):407-415.

24. Goddi A, Bonardi M, Alessi S. Breast elastography: a literature review. J Ultrasound 2012; 15(3):192-198.

25. Srinivasan S, Krouskop T, Ophir J. A quantitative comparison of modulus images obtained using nano indentation with strain elastograms. Ultrasound Med Biol 2004; 30(7):899-918.

26. Nightingale K. Acoustic Radiation Force Impulse (ARFI) Imaging: a Review. Curr Med Imaging Rev 2011; 7(4):328-339.

27. Palmeri ML, Nightingale K. Acoustic radiation force-based elasticity imaging methods. Int Focus 2011; 1(4): 553-564.

28. Popescu A, Sporea I, Sirli R, Bota S, Focsa $M$, Danila $M$, et al. The mean values of liver stiffness assessed by acoustic radiation force impulse elastography in normal subjects. Med Ultrason 2011; 13(1):33-37.

29. Holdsworth A, Bradley K, Birch S, Browne WJ, Barberet V. Elastography of the normal canine liver, spleen and kidneys. Vet Radiol Ultrasound 2014; 55(6):620-627.

30. Yashima $Y$, Sasahira N, Isayama $H$, Kogure $H$, Ikeda $\mathrm{H}$, Hirano $\mathrm{K}$, et al. Acoustic radiation force impulse elastography for noninvasive assessment of chronic pancreatitis. J Gastroenterol 2012; 47(4):427-432.

31. Mateen MA, Muheet KA, Mohan RJ, Rao PN, Majaz NMK, Rao GV, et al. Evaluation of Ultrasound Based Acoustic Radiation Force Impulse (ARFI) and esie touch Sonoelastography for Diagnosis of Inflammatory Pancreatic Diseases. Journal of the pancreas $2012 ; 13(1): 36-44$. 
32. Nogueira AC, Morcerf F, Moraes AV, Dohmann HFR. Ultra-sonografia com agentes de contrastes por microbolhas na avaliação da perfusão renal em indivíduos normais. Rev Bras Ecocardiografia 2002; 15(1):74-78.

33. Kalantarinia K, Okusa MD. Ultrasound contrast agents in the study of kidney function in health and disease. Ultrasound contrast agents in the study of kidney function in health and disease. Drug Discov Today Dis Mech 2007; 4(3):153-158.

34. Waller KR, O'brien RT, Zagzebski JA. Quantitative contrast ultrasound analysis of renal perfusion in normal dogs. Vet Radiol Ultrasound 2007; 48(4):373-377.

35. Brito MBS. Ultrassonografia modo B de alta resolução, modo Doppler e uso de contraste de microbolhas na avaliação testicular de gatos domésticos [dissertação de mestrado]. Universidade Estadual Paulista, São Paulo: Jaboticabal; 2015.
36. Volta A, Manfredi S, Vignoli M, Russo M, England GC, Rossi F, et al. Use of contrastenhanced ultrasonography in chronic pathologic canine testes. Reprod Domest Anim 2014; 49(2):202-209.

37. Takeda CSI, Carvalho CF, Chammas MC. Ultrassonografia contrastada na medicina veterinária - revisão. Clínica Veterinaria 2012; 17(101): 108-114.

38. Rickes S, Uhle C, Kahl S, Kolfenbach S, Monkemuller K, Effenberger $\mathrm{O}$, et al. Echo enhanced ultrasound: a new valid initial imaging approach for severe acute pancreatitis. Gut 2006; 55(1): 74-78. 